\title{
Опера в контексте посткультуры: игры с классикой и конфликт интерпретаций
}

\begin{abstract}
Аннотация: в статье рассмотрены проблемы, с которыми сталкивается классическая опера в эпоху «посткультуры», когда постмодернистские культурные черты (такие как фрагментация, культурный плюрализм, утрата чувства истории) стали доминировать в художественной культуре. Особое внимание уделяется проблеме времени в опере, которое рассматривается автором как время сюжета, время композитора и время слушателя/зрителя. На ряде примеров из современной практики «режоперы» показывается, что свободное перемещение времени сюжета не всегда оправданно, требует тщательного внимания ко всем аспектам произведения и может разрушить стилистическое единство последнего. Выделены несколько типов темпоральных структур и их возможных интерпретаций с акцентом на архетипичные образы, являющиеся предметом многочисленных экспериментов. Автор показывает закономерность плюрализма трактовок классических образов, призывая, в то же время, к сохранению традиционных ценностей культуры и к отказу от модернизации как самоцели.
\end{abstract}

Ключевъе слова: культурология, искусство, классика, посткультура, постмодернизм, опера, интерпретация, темпоральность, модернизация, сюжет.

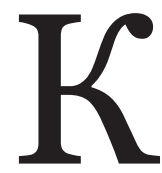
ультуру конца XX - начала XXI века нередко называют посткультурой, подчеркивая, что ее формирование происходило и происходит под большим влиянием идей и практик постмодернизма. Мы также будем пользоваться термином «посткультура ${ }^{1}$, чтобы показать темпоральную специфику и обусловленность явлений, происходящих в одном из видов искусства, а именно в опере, и попытаемся показать, что этот жанр во многом находится под влиянием тех процессов, которые один из наиболее известных исследователей постмодернистской культуры $\Phi$. Джеймсон выделяет в своей работе «Постмодернизм и общество потребления» (1983), а затем развивает в фундаментальном труде «Постмодернизм, или культурная логика позднего капитализма» ${ }^{2}$.

Одной из важнейших особенностей постмодернизма является то, что он предполагает стирание старой грани между «высокой» и массовой культурой, что привело к созданию многочисленных гибридных художественных форм и расширило практически до бесконечности возможности интерпретации тек-

\footnotetext{
${ }^{1}$ Термин уже вошел в исследовательский дискурс. См. определение В. Бычкова (Корневище оБ. Книга неклассической эстетики. М.. 1999), а также нашу работу; Шапинская Е.Н. Культурологический дискурс после постмодернизма// Обсерватория культуры, № 6, 2010.

${ }^{2}$ Jameson, F. Postmodernism, or, the Cultural Logic of Late Capitalism. L.-NY, 1991
}

стов прошлого. Еще одной весьма наглядно проявляющейся в современных культурных практиках чертой посткультуры стало ослабление чувства истории, что проявляется в «шизофреническом характере» и структуре темпоральных искусств. Джеймисон также отмечает новый эмоциональный тон, «интенсивность», который заменяет прежние способы соотнесения с объектом. Именно эти характеристики представляются для нас весьма важными в понимании того, что происходит сегодня на оперной сцене.

Выбирая оперу как область множественных репрезентаций, манифестации взаимоотношений сегодняшнего дня и прошлого, исторических реминисценций как объекта постмодернистской игры, мы рассматриваем ее не как академический жанр, относящийся исключительно к области элитарного искусства, а как часть живой художественной жизни наших дней, где постмодернизм давно стер грани между «высоким» и «низким» искусством, а массовая культура охватила все глобальное мировое пространство, оказав через тотальную медиатизацию несомненное влияние на четко ограниченные в прошлом поля различных видов искусства. Опера сегодня вышла далеко за пределы театров и концертных залов, не только путем «механического репродуцирования» (термин В. Беньямина) через записи, но и в многочисленных фестивалях 


\section{Культура и искусство 3(15) • 2013}

и концертах под открытым небом, собирающим аудитории не меньше, чем рок-концерт или футбольный матч. Оперные спектакли ведущих театров становятся доступными в глобальных масштабах через мировые трансляции в кинотеатрах, а последние новости из оперного мира мгновенно распространяются через различные сайты и форумы ${ }^{3}$. Такое расширение пространства не могло не сказаться и на самой опере, как с точки зрения зрелищности, так и множественности интерпретаций музыкального и сюжетного материала. Опера привлекает к себе профессионалов в области театра и кино, становясь так называемой «режоперой» со второй половины XX века. «Театральный мир дал опере многих режиссеров. Патрис Шеро уже был театральной звездой, когда поставил знамениты юбилейный цикл вагнеровского «Кольца» на Байрейтском фестивале между 1976 и 1980. Известные театральные режиссеры, такие как Питер Брук, Джорджио Стрелер и Гарри Купфер также занялись оперой со значительным успехом, как и Ингмар Бергман, шведский кино- и театральный режиссер. ...Театральное влияние в опере продолжается и по сей день» 4 .

Для нас опера представляет интерес как культурный феномен наших дней, который содержит в себе многие вопросы, непосредственно касающиеся особенностей современной культуры (или посткультуры) в целом. С точки зрения социологии культуры представляет интерес мотивация публики: что люди находят интересного в опере, каковы причины посещения фестивалей и концертов? C другой стороны, если мы исследуем тексты культуры, что является очень важным направлением в современных исследованиях и основывается на идеях столь влиятельного подхода как Cultural studies, то нас интересуют смыслы, которые несет в себе оперный спектакль. В данном случае мы оставляем за скобками чисто музыкальную составляющую, хотя она, несомненно, является важнейшей частью оперного спектакля. С музыкальной точки зрения опера исследована глубоко и всесторонне музыковедами и историками искусства. Что касается культурных смыслов оперы, она изучена крайне мало, как в социологическом, так и культурфилософском аспектах.

3 Для примера приведу сайты, посвященные анализу и популяризации оперы: Belcanto.ru, Classic-Music.ru, Оперный форум, Опера в кинотеатрах.

${ }^{4}$ Riding A., Dunton-Downer L. Opera. Penguin, L.-NY, 2006. P. 34 .
Среди исследований такого рода несомненный интерес представляют две работы, написанные в разное время и с разных позиций, но вводящие оперу в значимое культурное пространство, находящееся за рамками музыковедения и узкого круга любителей-меломанов. Во-первых, это работа Т. Адорно «Введение в социологию музыки», где немецкий философ, сам имеющий музыкальное образование и глубоко знающий музыкальный материал, говорит о кризисе оперы с точки зрения ее несоответствия вызовам времени. «Непрекращающийся кризис оперы сказался уже и в кризисе самих возможностей оперной постановки. Режиссеру приходится постоянно выбирать между скукой, заплесневелостью старого, жалкой и ничтожной актуальностью - обычно десятым тиражом тенденций живописи и пластики - и мучительным и неловким подновлением старья, с помощью притянутых за волосы режиссерских идей. Эти попытки мотивируются страхом потерять для репертуара общепризнанные, хотя и шитые белыми нитками, классические произведения, - вроде “Летучей мыши” и “Цыганского барона”, где невозможно больше замазывать идиотизм сюжета. Но напрасно бьется режиссер и с лебедем Лоэнгрина и Самиэлем Волчьего ущелья. То, что он тщится осовременить, - это не только чисто сюжетно требует всего этого реквизита, но и по своему внутреннему смыслу. Если убрать реквизит, то перед режиссером отнюдь не откроются Елисейские поля вещности, напротив, он впадет в прикладничество. Модернизм душит современное искусство. Барочные и аллегорические элементы оперной формы, глубоко связанные с ее истоками и смыслом, утратили ореол привлекательности. Беспомощно, голо, иногда комично, они лезут в глаза, становясь добычей юмора, вроде обычной театральной шутки: “Когда отходит следующий лебедь?”5 Кризис оперы отмечает и глубокий исследователь оперы, сам выдающийся исполнитель своего времени, Дж. Лаури-Вольпи, который также связывает его с модернизмом, вернее, с присущей ему технологизацией. «...кризис оперного театра не спонтанный, а подготовленный и вызванный теми, кто стремится принизить ценность индивидуальности... Эра техники заглушила мелодичное пение,

${ }_{5}$ Адорно Т. Введение в социологию музыки. Университетская книга. М. - Спб, 1999 С. 72. 


\section{Философия культуры}

которое сегодня слушает и ценит ничтожное меньшинство» ${ }^{6}$. Мнение это весьма созвучно с критикой в адрес культурной индустрии, которую развивал Т. Адорно, что подтверждает влияние общекультурных тенденций на классические жанры искусства. Несмотря на то, что оперное искусство сегодня полностью испытало на себе процессы модернизации, обновляя сюжет и раздвигая временные рамки произведения с большим или меньшим успехом, некоторые мысли Адорно остаются актуальными, в частности с точки зрения «неловкого подновления старья», которое часто выдается за креативность и новизну режиссерского решения. Вопрос времени ставится Адорно очень остро - как поступать с текстами прошлого сегодня, пытаться осовременить их или придерживаться контекста их создания и воспроизводить его с учетом требования времени? На этот вопрос ищут ответ деятели культуры самых разных направлений, и его решение связано с общим отношением к истории, доминирующим в посткультуре 7 .

Обратимся еще к одному примеру культурологического исследования оперы - к анализу Э.Саидом оперы Верди «Аида» в книге «Культура и империализм». Основатель школы постколониальных исследований ставит задачу, важную как в социальном, так и общекультурном плане - «проследить роль эстетического компонента в освоении Египта и Индии и управлении ими» ${ }^{8}$ и решает ее на примере истории постановки «Аиды». Эта опера, по мнению Э. Саида, вышла за рамки феномена музыкального театра, закрепляя в сознании европейцев стереотипы «Востока», который представлен в ней как «экзотическое, отдаленное и древнее место, где европейцы могут продемонстрировать свою силу» ${ }^{9}$. Саид рассматривает оперу как феномен, выходящий за рамки искусства. «Аида», как и вся оперная форма в целом, представляет собой гибрид, радикально неоднородное произведение, которое в равной степени принадлежит и истории культуры, и историческому опыту заморского господства»10. C

\footnotetext{
6 Лаури-Вольпи Дж. Параллельные голоса. М.. Аграф, 2011. C. 283.

${ }_{7}$ См.: Напинская Е.Н. Образы прошлого в культуре постмодернизма: репрезентация или пастиш?// Культура и искусство, № 3 (9), 2012.

8 Саид Э.В. Культура и империализм. Санкт-Петербург, «Владимир Даль», 2012. С. 240.

${ }_{9}$ Там же. С. 242.

${ }^{10}$ Там же. С. 247.
}

позиций исследователя колониального господства Саид заинтересован в опере именно этим аспектом широко представленных в ней властных отношений, нас же интересует в его определении неоднородность оперного текста, в частности, связанная со структурами темпоральности. Последние становятся предметом самых разных творческих поисков и экспериментов, которые в эпоху посткультуры приобретают все более фрагментарный и бессвязный характер, утрачивая какую-либо временную определенность.

Время в опере. Приведенные нами примеры говорят о важности оперного жанра для общекультурной проблематики. Мы выделим из широкого круга культурологических проблем, касающихся слияния высокой и массовой культуры, визуализации в «обществе спектакля», глобализации и медиатизации тему игры с историей в эпоху «постистории», где многие смыслы культурных текстов изменились по сравнением с культурой эпохи Т. Адорно, по отношению к которой еще не применялась приставка «пост-». Постмодернистские тенденции культуры, в которых история предстает как множество фрагментов, в которые авторы играют по своему усмотрению, изменила и понятие истории применительно к опере или, вернее, понятие времени. Для того, чтобы представить себе всю сложную темпоральную структуру современной «режоперы», выделим 3 типа времени в опере:

Время действия, которое в опере часто условно. Перенос действия в далекие эпохи или экзотические страны дает возможность изображать страсти и эмоции в некоем условном контексте, создающем специфическую оперную эстетику, как, к примеру, в «Аиде», или выражать архетипические модели через мифологические сюжеты, что происходит в опеpax Вагнера. Может иметь место и соотнесение с реальными историческими событиями («Иван Сусанин», «Борис Годунов»), которые часто становятся фоном для любовных драм и других человеческих взаимоотношений.

Время композитора. К какому времени ни был отнесен сюжет оперы, к эпохе современной композитору, к условному или историческому прошлому, его репрезентация всегда будет обусловлена стилистическими особенностями эпохи композитора. Во многом этот процесс сродни исторической теме в литературе, которая часто служит предлогом поговорить о насущных проблемах современности. 
Культура и искусство 3(15) • 2013

Когда композитор переносит сюжет во время, музыкальная стилистика которого идет вразрез со стилем эпохи композитора, возникает необходимость изменить время действия для более органического восприятия. Примером такого рода является «Пиковая дама» Чайковского, где первоначально, согласно либретто М.Чайковского, действие перенесено в XVIII век, но герои, вдохновленные самым «странным» прозаическим произведением Пушкина и несущие на себе отпечаток всей русской культуры XIX века, совершенно неубедительны в пасторально-рокайльной стилистике века Екатерины, поэтому наиболее успешные постановки «Пиковой дамы» перемещают время действия в пушкинскую эпоху, хотя в либретто от литературного первоисточника осталась неизмененной лишь сцена в спальне графини.

Время зрителя/слушателя, которое выдвигает свои требования к оперному действу ${ }^{11}$. Именно это время чаще всего служит основой перемещения сюжета в эпоху зрителя. Как мы покажем дальше, в этом содержатся многие возможности, но и многие опасности для произведения искуссва.

Стратегии постановок и игры со временем. Различные виды оперного времени определяют и те стратегии постановок, которые так или иначе воплощают эти темпоральные структуры, зачастую играя различными видами времени и перемещаясь между ними. Условно можно обозначить стратегии оперных постановок по отношению ко времени как модернизация, воссоздание аутентичности, универсализация. Эти выделенные мной виды трактовки времени, или «историзма», очень близки к типологии оперной режиссуры, которую предложил известный современный аналитик, критик и исследователь оперы Е. Цодоков. Он выделяет четыре теоретически возможных способа (или типа) режиссерского «прочтения» оперы :

«1. Натурализм, или тотальный аутентизм. Это попытка поставить оперу точно так, как это было в стародавние времена на мировой премьере.

2. Исторический реализм. В данном случае суть заключается в бережном сохранении традиций прошлого, но с учетом изменившихся современных исторических, жизненных и художественных реалий.

\footnotetext{
${ }^{11}$ Подробнее см.: Напинская Е.Н. Опера как пространство эскапизма// Полигнозис, №1-4, 2012.
}

3. Постмодернистская «современная режиссура». Этот, столь широко распространившийся во 2-й половине 20 в. режиссерский подход, подразумевает полный разрыв с авторским замыслом и классическими постановочными традициями. Прежде, чем перейти к четвертому типу режиссерского прочтения оперы, подведем некий промежуточный итог.

4. Музыкально-поэтический символизм (так его можно условно назвать, не путая с историческим понятием символизма, как художественного стиля). Данный постановочный принцип должен максимально использовать основные свойства музыки, как определяющей субстанции оперы, и в первую очередь ее непонятийную основу (в отличие от драматического искусства). ...Именно здесь эффективен основной закон визуализации оперной постановки, который мы неоднократно уже декларировали: Любые внемузыкальные художественные средства интерпретации в оперном искусстве плодотворны в той мере, в какой они усиливают и «обнажают» художественные смыслы основной оперной субстанции - музыки» ${ }^{12}$.

Рассматривая предложенные музыковедом точки зрения на возможности оперной постановки сегоня, мы видим, что как типология, так и оценка результатов во многом совпадают с нашим культурологическим анализом, что создает надежду на появление междисциплинарных исследований в области художественной культуры, которые дадут возможность лучше понять явления «посткультуры», ускользающие от традиционного анализа в рамках устоявшихся академических дисциплин.

Модернизация оперы как главный тренд наших дней. Модернизация является, пожалуй, самой распространенной режиссерской практикой наших дней. Среди оперных режиссеров стало модным приближение оперы к времени зрителя, перенесение сюжета в современность. Это, в частности, объясняется стремлением привлечь молодежь в оперу. Как яркий пример такого «омолаживания» оперы можно привести постановку «Богемы» Пуччини на Зальцбургском фестивале 2012 г. (Режиссер Дамиано Микилетто), где персонажи предстают в виде субкультурной молодежи современного мегаполиса, в частности исполняющая роль Мими Анна Не-

\footnotetext{
${ }^{12}$ Цодоков E. Опера - уходящая натура.

Cм.: http://www.operanews.ru/history54.html.
} 


\section{Философия культуры}

требко появляется в образе «готки» со всеми атрибутами - сигаретой, черными ногтями и т.д. Возникает вопрос: разве молодежи это интересно? Или оперные певцы, даже (относительно) молодые и красивые, могут напоминать субкультурных персонажей, в которые их превратила идея режиссера? Эти персонажи гораздо лучше представлены в шоубизнесе, рок-опере или «хип хопере». Самая большая проблема такого рода постановок - это абсолютное несовпадение визуального и музыкального ряда - каждая эпоха имеет свой стиль музыкального выражения, и представители молодежной культуры не будут выражать свои чувства так, как это делали герои другой эпохи, когда чувства еще не были сведены к сексуальным отношениям, а их выражения были гораздо более цветисты, чем это приято в роке или рэпе. Несовпадение компонентов оперного спектакля такого рода заметно даже неискушенному зрителю/ слушателю, вызывая недоумение скорее, чем интерес. Что касается предпочтений современной молодежи, они вовсе не ограничены репрезентациями их собственных субкультурных стилей. Если мы посмотрим на культурную продукцию, сформировавшую вкусы сегодняшней молодежи, то увидим, что она весьма далека от повседневных реалий наших дней. Начиная со «Звездных войн» и кончая вампирскими сагами, культовые тексты современной молодежной культуры обращаются к необычному, к фантазии, к сказочным образам, к загадочным героям, очень далеким от повседневной жизни. С этой точки зрения фантазийно-сказочное окружение оперных героев может быть более привлекательным, чем надоевшие мотоциклы, машины и мобильные телефоны на оперной сцене. Понимание специфики времени зрителя очень важно для восприятия оперного спектакля как рассказа о чувствах и переживаниях человека, понятных и близких нашему современнику, но это не означает примитивного соотнесения с «вещным» контекстом наших дней. Кроме того, свободное перемещение имеющего литературную основу сюжета, ставшего неотъемлемой частью культурной памяти и традиции, может вызывать неприятие и раздражение той части публики, которая еще сохранила связь с традицией. Так, В.Самохвалова в своей книге «Безобразное» ссылается на современную версию оперы «Евгений Онегин» в постановке Д.Чернякова, «Моцарта и Сa- льери» в версии «Геликон-оперы» и «Бориса Годунова» в постановке британского режиссера У.Доннована, причем автор не скрывает своего отрицательного отношения к подобным постмодернистским играм с историей. «Если это не безобразное, в основе которого... лежит злая и как бы иномирная (в своей непричастности к истинно человеческому) ирония по поводу человека и мира, пародия на человеческое и т.п., и в то же время совершенно «отвязанное» лицедейство, то к какой категории можно причислить оценку подобного?... Представляется безобразной сама тенденция столь дико искажать классика не просто национального, но мирового масштаба» ${ }^{13}$. Можно по-разному оценивать художественные эксперименты с классикой, которые, кстати, не являются исключительно явлением посткультуры, но позиция В.Самохваловой вызывает уважение своей опорой на культурную традицию и вечные ценности, которые никто не отменял во все эпохи и которых так не хватает людям «посткультуры» .

Тоска по аутентичности. Воссоздание «аутентичности» является еще одной весьма распространенной стратегией в оперных постановках. Наиболее яркий пример таких зрелищных спектаклей, скрупулезно воссоздающих реалии времени, в которое помещен сюжет, - режиссерские работы Ф. Дзефирелли, ставшие классикой XX века. Режиссер погружает слушателя/зрителя в красочные миры «Аиды», «Травиаты» и многих других известных опер, создавая присущую ему избыточность персонажей, декораций, животных, придавая спектаклю масштабность, создавая барочную заполненность пространства, в которой героям легко затеряться среди статистов, а музыка иногда становится фоном визуальности. Дзефирелли - признанный мастер исторической сценографии, и в случае масштабных постановок, соответствующих сюжету, это вполне оправдано, но лирическая и интимная линия могут легко затеряться в этом великолепии. Существует мнение, что «аутентичное» прочтение сюжета с его реалиями - костюмами, обстановкой и т.д. безнадежно устарело, и такие постановки обречены. Тем не менее, последняя работа $Ф$. Дзефирелли - постановка «Дон Жуана Моцарта» на Арена ди Верона (2012), выполненная

\footnotetext{
${ }^{13}$ Самохвалова В.И. Безобразное: Размышления о его природе, сущности и месте в мире. М.: Брис-М., 2012. С. 272.
} 


\section{Культура и искусство 3(15) • 2013}

со всей возможной барочной роскошью, показывает стойкость «костюмной» оперы на современной сцене.

Говоря об аутентичности, мы подразумеваем изначально присущую опере условность, репрезентацию не столько того или иного исторического контекста, сколько представление о нем зрителя. Это условное историческое прошлое продолжает представать на оперной сцене в самом экзотическом виде, несмотря на все открытия историков, массу документальных программ на исторические темы и т.д. Э Саид, о котором мы уже писали выше, в качестве такого псевдо-историзма приводит пример постановки «Аиды» в Цинцинатти-опера (1986). «Пресс-рилиз объявляет, что «в сцене триумфа примут участие следующие животные (по одному экземпляру: трубкозуб, осел, слон, боа-констриктор, павлин, тукан, краснохвостый ястреб, белый тигр, сибирская рысь, какаду и гепард - всего 11 штук. А всего в постановке задействован 261 человек, включая 8 главных исполнителей, 117 хористов, 24 танцовщика и 1 сверхштатный работник, включая 12 дрессировщиков и 11 животных. Вот какова «Аида» - более-менее сыроватое произведение, комичное изобилие, ловкая подделка, игранная и переигранная с несравненной вульгарностью в банях Каракаллы» ${ }^{14}$.

Для постсовременного слушателя/зрителя, у которого история представляется в виде множества фрагментов, вполне убедительными предстают стилизованные образы, как бы подсмотренные нашим современником в тайное окно, раскрытое в некое отдаленное и романтизированное прошлое. Очень удачным примером такого рода стала постановка «Лючии ди Ламмермур» Доницетти (режиссер А.Шапиро) в московском театре им. Станиславского и НемировичаДанченко. Декорации создают условность, подчеркивающую общее настроение, а стилизованные костюмы не столько исторически точны, сколько отвечают представлениям о романтическом прошлом.

«Аутентичные» постановки становятся все более востребованными, поскольку уставшая от бесконечных модернизаторских поисков публика уже не воспринимает как нечто новое бесконечные признаки сегодняшнего дня, тем более, что фантазия режиссеров в этом смысле явно истощается, а эпатаж имеет свои границы и быстро становится мало

\footnotetext{
${ }^{14}$ Саид Э. Культура и империализм. С. 265.
}

интересен. Примеров такого рода мы видим множество, как на мировой, так и на отечественной оперной сцене.

Архетипичный герой вне времени и пространства. Третьим выделенным нами подходом к оперным постановкам является универсализация, которая может быть, с одной стороны, трактовкой универсального сюжета, сказочного или мифологического, с другой - интерпретацией «вечного» сюжета или архетипического персонажа. Мифологический сюжет дает, несомненно, большие возможности для режиссерской фантазии, поскольку он связан не с исторической конкретикой, а вечными истинами, ценностями и чувствами. Еще больше возможностей для разнообразных интерпретаций дают архетипичные оперные образы, которые, казалось бы, легче всего поддаются перемещениям по различным историческим временам. Плюрализм интерпретаций классических произведений обусловлен, по мнению Т. Злотниковой, которая провела серьезное культурологическое исследование современной режиссуры, самим процессом историко-культурного развития искусства, который «... позволил установить представление о том, что механизм интерпретации применим к любому тексту классического произведения, поскольку такой текст является открытой системой, содержащей непознанный запас смыслов» ${ }^{15}$. Полностью соглашаясь с определением классического текста как открытой системы, выскажем некоторые опасения по поводу бесконечного множества интерпретаций, которые означают не только «смерть автора» (как ее понимал Р. Барт), но и полную деструкцию произведения-источника.

Наиболее известными оперными персонажами такого рода являются Дон Жуан и Кармен, герои историй, которые могли бы произойти в любую эпоху и в любой культуре, сюжетов, которые в литературе называются «бродячими» (или, как я назвала их в своей книге «Дискурс любви», итерабильным, то есть способным к перемещениям) ${ }^{16}$. Эти сюжеты и персонажи дают богатейшие возможности режиссерской фантазии и порождают наибольшее количество интерпретаций, основанных на помещении сюжета в какую-либо,

\footnotetext{
15 Злотникова Т.С. Эстетические парадоксы режиссуры: Россия, XX век. Ярославль, 2012. С. 49.

${ }^{16}$ См.: Шапинская Е.Н. Дискурс любви. М., Прометей, 1997.
} C. 161-209. 


\section{Философия культуры}

выбранную по идее (или причуде) режиссера историческую эпоху или же создающие некое условное вневременное пространство. Если рассмотреть вопрос архетипичного героя и конекста, все оказывается гораздо сложнее.

Обратимся вначале к «Дон Жуану» Моцарта, который в наши дни ставится очень часто, в театрах, на фестивалях, в концертном исполнении, причем трактовки как главного героя, так и эпохи, в которой ведет счет своим победам великий обольститель, крайне разнообразны и противоречивы, что во многом обусловлено загадочностью этого произведения, содержащего в себе самые разные возможности прочтения. «За годы, прошедшие со дня смерти Моцарта, ученые, критики, дирижеры предлагали свою трактовку его «Дон Жуана. Одни были, очевидно, движимы любовью и уважением к оригиналу, другие - не в меру экстравагантные - искажали его порой чуть ли не до надругательства» ${ }^{17}$. Хорошо известно высокое мнение Э.Т.А. Гофмана о «Дон Жуане», но причины такой оценки вовсе не столь прозрачны. Во-первых, великий немецкий романтик писал о моцартовском шедевре в 1813 г., когда великие оперы XIX века еще не появились. Кроме того, взгляд Гофмана обусловлен его собственной позицией, приводящей к выделению романтического элемента музыки Моцарта, в которой он видит, прежде всего, столкновение человека с неведомыми злокозненными силами, которые его окружают, готовя ему погибель» ${ }^{18}$.

Пытаясь найти разгадку «Дон Жуана», смысл послания Моцарта, созданного им в контексте своего времени, рокайльной эпохи, необходимо попытаться понять то, что мы обозначили как время композитора. Такое обращение очень важно для понимания интенции автора, неизбежно находящегося в пространстве культурных доминант своего времени, даже если он восстает против них. Выдающийся английский искусствовед К. Кларк в своем исследовании европейской цивилизации пишет о Моцарте: «Конечно, большая часть музыки Моцарта написана в стиле XVIII века. Он полностью чувствовал себя дома в этом золотом веке музыки, и был настолько полновластным хозяином ее форм, что не считал нужным разрушать их. Он любил ясность и четкость, которые были

${ }^{17}$ Тито Гобби. Мир итальянской оперы. М.. Радуга, 1989. C. 27.

${ }^{18}$ Гофман Э.Т.А. Дон Жуан. - Собр. Соч.в 6 т. Т.1. М.. Художественная литература, 1991. С. 83. доведены до совершенства в музыке его времени» ${ }^{19}$. Что касается образа главного героя, вокруг которого строятся многочисленные интерпретации, он является вполне типичной фигурой галантного века, когда победы над женщинами были неотъемлемой частью светской жизни. Гедонизм становится жизненной философией. Э. Фукс пишет в своей «Истории нравов»: «Так как жизнь только коротенькое путешествие, то следует совершить его как можно комфортабельнее и веселее. Для этой цели необходимо игнорировать, как будто они не существуют, все осложнения, которые могут помешать этому удовольствию... Любовная связь становится в эту эпоху договором, не предполагающим взаимных обязательств: его можно разорвать в любой момент» ${ }^{20}$. Эротизм эпохи обуславливает и невероятное количество побед Дон Жуана, объясняя, почему женщины так легко поддавались соблазну? Фукс пишет, основываясь на большом количестве документов, о беспредельном увлечении каждой женщины культом галантности: «...никогда женщины до такой степени не были помешаны на мужчинах, как тогда» ${ }^{21}$. В этих условиях при отточенном, как у Дон Жуана, до совершенства искусства соблазнять, перечень его побед уже не представляется чем-то гипертрофированным. Костюм этой эпохи также служит усилению общего настроения эротизма. «Костюм - это та форма, которую дух придает телу во вкусе времени.... Идеал красоты теперь осуществляется при помощи одежды, сосредотачивается в одежде. Отделить человека от его костюма невозможно, ибо они - единое целое» ${ }^{22}$. Когда мы видим героев Моцарта в современных деловых костюмах, эротизм или исчезает или превращается в ироническую насмешку над нравами совсем другой эпохи, где культу наслаждения отводится место в редкие часы свободы от деловой офисной рутины. «Сегодня женолюбы являются продуктами самих преобразований в личной жизни, которые лежат на поверхности вещей, - пишет Э. Гидденс в своем исследовании любви и эротики в современном обществе, Они являются соблазнителями в эпоху, когда обольщение вышло из употребления, и это объясняет многое в природе их принудитель-

${ }^{19}$ Clark K. Civilisation. A Personal View. NY, Harper and Row, 1969. P. 241.

${ }^{20}$ Фукс Э. Иллюстрированная история нравов. Галантный век. М.. Республика, 1994. С. 168-169.

${ }^{21}$ Там же. С. 249.

${ }^{22}$ Там же. С. 111. 


\section{Культура и искусство 3(15) • 2013}

ности. “Обольщение” утратило многое из своего значения в обществе, в котором женщины стали гораздо более сексуально доступными для мужчин, чем когда бы то ни было прежде, хотя - и это носит решающий характер - и более равными им. Погоня за женщинами отражает это фундаментальное изменение в то же самое время, как и выражает изменение против него» ${ }^{23}$. Это мнение британского исследователя следовало бы, на наш взгляд, учесть тем, кто берется за постановку моцартовского шедевра сегодня.

Темпоральную обусловленность Дон Жуана подчеркивает и Н. Луман, обращаясь к изменениям в понимании любви, произошедшим со сменой средневековых представлений об идеальной любви на парадоксальность любви в эпоху барокко. «... Дон Жуан создает модель поведения, которая обладает более глубоким смыслом, чем стараются нас убедить последующие морализации... Непостоянство в это время становится необходимостью» ${ }^{24}$. Луман связывает это новое отношение к любви и соответсвующий ему код поведения с понятием страсти, которая дала человеку «свободу вести себя в сердечных делах без социальной и моральной ответственности» ${ }^{25}$. Таким образом, в опере Моцарта мы видим столкновение двух эпох и двух кодов поведения - апологии непостоянства и страсти в лице героя и необходимость моральной ответственности, которая пришла позже, в эпоху Просвещения и наложила свой отпечаток на неотвратимость наказания порока, которую воплощают «положительные» герои. Эта сложная и противоречивая игра эпох и стилей во многом объясняет загадочность и притягательность как самой оперы, так и ее героя.

Несмотря на темпоральную обусловленность, Дон Жуан выходит за границы своего времени, становясь предметом множества трактовок, тем более, что в данном случае время композитора и время героя не совпадают, так как история севильского соблазнителя уходит корнями в средневековье и оживает в барочной культуре. Несомненно, Моцарт трактует своего героя с позиций своего времени, но исторически герой не является современником композитора, что уже создает предпосылку к постановочному плюрализму.

\footnotetext{
${ }^{23}$ Гидденс Э. Трансформация интимности. Сексуальность, любовь и эротизм в современных обществах. М.-СПб, Питер, 2004. C. 103.

${ }^{24}$ Luhman N. Love as Passion. Cambridge-Oxford, Polity Press, 1986. P. 61.

${ }^{25}$ Там же. С. 60.
}

В то же время именно в «Дон Жуане» наиболее остро ощущается прорыв Моцарта за пределы своей эпохи. «Совершенство формы у него использовалось, чтобы выразить две характеристики, очень далекие от стиля рококо. Одна из них - особое ощущение меланхолии, доходящее почти до паники, которая так часто преследует гения в его изоляции. Другая характеристика полностью противоположна: страстный интерес в людях и человеческих взаимоотношениях.... Музыка довольно сложна, поскольку даже сегодня наши чувства в отношении Дон Жуана далеко не просты. Он самый неоднозначный среди героев-злодеев. Погоня за счастьем и за любовью, которая казалось такой простой и жизнеутверждающей, стала сложной и разрушительной, а его отказ раскаяться, делающий его героическим, принадлежит другой фазе цивилизации ${ }^{26}$. Именно эта неоднозначность и делает возможными самые разные интерпретации этого шедевра Моцарта и игру между героем и контекстом. Вопрос заключается в том, насколько убедительна та или иная трактовка и насколько она гармонирует с музыкальной стилистикой, определяя общее эмоциональное настроение. Э. Гидденс в своем анализе феномена обольщения говорит о темпоральной обусловленности образа Казановы, который был «...фигурой из общества, находящегося на пороге модернизма... Для него секс был нескончаемы поиском, который приходил к своему итогу не в результате самоосуществления или мудрости, а только с дряхлостью старости» ${ }^{27}$. Эти слова вполне применимы к моцартовскому Дону, который не дожил до старости благодаря роковому вмешательству, которому придано значение моральной силы наказания и отмщения.

Анализируя различные постановки шедевра Моцарта, мы видим, что наиболее удачные из них, несущие в себе отблеск гениальности композитора, основаны на глубоком понимании образа героя, который изначально содержит в себе амбивалентность, приводящую к акценту на ту или иную сторону своего характера в интерпретации этого образа. Мы выделили две философские позиции по отношению к образу Дон Жуана, противоположные, но в то же время дополняющие друг друга и дающие понимание того, почему образ

\footnotetext{
${ }^{26}$ Clark K. Civilisation. P. 242-243.

${ }^{27}$ Гидденс Э. Трансформация интимности. Сексуальность, любовь и эротизм в современных обществах. М.-СПб, Питер, 2004. C. 102.
} 


\section{Философия культуры}

распутника, кутилы и повесы продолжает привлекать интеллектуалов и художников. Иллюстрируя эти позиции, мы рассмотрим ниже две постановки оперы Моцарта, воплощающие эти позиции и создающие разные, но одинаково убедительные образы, дающие ответ на загадку великого соблазнителя как с позиций рефлексии, так и культурных доминант своей эпохи. Герой в данном случае важен еще и потому, что у него мало музыкального материала, на котором исполнитель мог бы раскрыть свои возможности и выстроить характер музыкальными средствами. Дон Жуан поет в опере меньше остальных героев, не имея даже масштабной арии. Тем не менее, он является центральной фигурой, вокруг которой строится сюжет, отношения и судьбы других героев, в которые он вторгается, безжалостно их ломая. Одна из самых известных философских интерпретаций образа Дон Жуана содержится в работе А. Камю «Абсурдный человек». Французский философ-экзистенциалист говорит о радости жизни как об основной стороне характера Дон Жуана. «Смех и победоносная дерзость, прыжки из окон и любовь к театру - все это ясно и радостно. Всякое здоровое существо стремится к приумножению. Таков и дон Жуан. Кроме того, печальными бывают по двум причинам: либо по незнанию, либо из-за несбыточности надежд. Дон Жуан все знает и ни на что не надеется ${ }^{28}$. Дон Жуан для Камю - образец абсурдного человека, который «ничего не предпринимает ради вечности и не отрицает этого ${ }^{29}$. Со свойственной абсурдному человеку неверием в глубокий смысл вещей Дон Жуан идет по жизни, не оглядываясь на прошлое и живя тем чувством, которое поглощает его в данный момент. «Абсурдному человеку свойственно неверие в глубокий смысл вещей. Он пробегает по ним, собирает урожай жарких и восхитительных образов, а потом его сжигает. Время - его спутник, абсурдный человек не отделяет себя от времени» ${ }^{\circ}$. Сценическое воплощение образа такого героя предполагает легкий переход от одной радостной победы к другой, наслаждение всеми чувственными удовольствиями, которые позволяет Дон Жуану его социальное и материальное положение, что подчеркнуто победно-радостным мотивом в музыкальных сценах пирушек и раз-

\footnotetext{
${ }^{28}$ Камю А. Бунтующий человек. М., Изд-во политической литературы, 1990. С. 62.

${ }^{29}$ Там же. С. 60.

${ }^{30}$ Там же. С. 63.
}

влечений, которые так любит устраивать герой. Любовные утехи сопровождаются гедонистическим потреблением вина и пищи, музыкой и танцами.

Противоположную трактовку образа Дон Жуана дает Гофман, который, как мы уже отмечали, пишет с позиций романтика и выделяет в творении Моцарта романтический элемент, который еще только брезжит в этом великом творении, не выходящим за рамки предписанной временем формы, но содержащим новые настроения. Соответственно, главным в герое становится не его безудержный гедонизм, а «другость», невозможность вписаться в рамки социальных условностей, выход из которых он видит в бесконечных победах над женщинами. Он использует тот дар, который ему дала природа, и дар этот несет в себе гибель не только несчастных брошенных возлюбленных, но и его самого. «Так и кажется, будто он владеет магическими чарами гремучей змеи; так и кажется, что женщины, на которых он бросил взгляд, навсегда обречены ему и, покорствуя недоброй силе, стремятся навстречу собственной погибели ${ }^{31}$. Знаменитую арию Дон Жуана "Fin ch'han dal vino...", в которой герой выражает намерение присоединить еще несколько красавиц к своему списку Гофман трактует как протест героя против своего окружения. «Дон Жуан, нисколько не таясь, раскрыл свою мятущуюся душу, свое презрение к окружающим его людишкам, созданным лишь для того, чтобы он, себе на потеху, пагубно вторгался в их тусклое бытие» ${ }^{2}$. В рассказе Гофмана об увиденном им спектакле мы видим смену настроения игривости рококо на романтизацию мрачного и непонятого героя, что тревожило зрителей, больше настроенных на легкость и пикантность истории из галантного века. Гофман объясняет глубокий смысл музыки Моцарта, как бы не соответствующий «кутиле, приверженному вину и женщинам»: «Дон Жуан с жаром требовал от жизни всего того, на что ему давала право его телесная и душевная организация, а неутолимая жгучая жажда, от которой бурливо бежит по жилам кровь, побуждала его неустанно и алчно набрасываться на все соблазны здешнего мира, напрасно чая найти в них удовлетворение»33. Воплощение такого героя требует исполнителя, наделенного харизматичностью и принявшего для себя

\footnotetext{
${ }^{31}$ Гофман Э.Т.А. Дон Жуан. С. 84.

${ }^{32}$ Там же. С. 85.

${ }^{33}$ Там же. С. 90.
} 


\section{Культура и искусство 3(15) • 2013}

настроение разочарования и неудовлетворенности, что опять-таки требует определенного контекста, в котором такого рода герой может существовать органично.

Величие архетипичных образов в том, что каждая эпоха может «вычитывать» в них то, что близко ей по духу, но при этом вовсе не обязательны эксперименты с формой, которые бывают скорее неудачными и отвлекают от постижения внутренней сути образов и человеческих отношений. «Окруженный всеми ими, само средоточие драмы - Дон Жуан, загадочный, пленительный и отталкивающий. В его адрес немало задано вопросов, а ответов, достойных внимания, сыщется не так много», - пишет Тито Гобби о «Дон Жуане»34. В поисках ответа мы выделили две версии оперы, которые, на наш взгляд, являются блестящими, хотя и совершенно различными интерпретациями «Дон Жуана» - это легендарная постановка шедевра Моцарта на Зальцбургском фестивале 1954 г. (реж. Герберт Граф, Пол Циннер) и Ф. Дзефирелли на «Арена ди Верона» 2012 г., которую мы уже упоминали выше. Эти спектакли разделяет почти 60 лет, что неизбежно сказывается на их стилистике, на манере исполнителей, на темпе и динамике оркестра. Тем не менее, они сопоставимы по близости к пониманию образа главного героя, выраженному в приведенных нами концепциях А.Камю и Э.Т.А. Гофмана, причем и ту, и другую можно отнести к «аутентичной» постановочной традиции.

В зальцбургском спектакле, приобретшему статус классики, во многом благодаря дирижерскому мастерству В.Фуртвенглера, образ Дон Жуана создает Чезаре Сьепи, один из лучших исполнителей этой роли в $\mathrm{XX}$ веке, герой исполнен радости и полноты жизни, о которых писал А.Камю. Все его приключения и похождения - результат избытка жизненной энергии и широты натуры, которая нуждается в новых впечатлениях и получает от них искренне удовольствие. Препятствия воспринимаются им как досадное недоразумение, которое легко преодолеть, и когда он наталкивается на непреодолимость воли Командора, его охватывает не столько страх, сколько раздражение от того, что он перестает владеть ситуацией. Финал, при всей его интенсивности, не несет в себе роковой развязки судьбы,

34 Тито Гобби. Мир итальянской оперы. М.. Радуга, 1989. C. 32 . избранной по своей воле и ведущей к неминуемому, скорее, это неблагоприятное для героя стечение обстоятельств. Чезаре Сьепи абсолютно убедителен в своем неприкрытом гедонизме, готовности отдаваться всем своим увлечениям и радостному шествию по жизни, которое прерывается неудачным для него стечением обстоятельств. Противоположная, но не менее убедительная интепретация образа севильского соблазнителя создана Франко Дзефирелли и Ильдебрандо Д'Арканджело, одним из самых известных исполнителей этой роли в наши дни, в уже упомянутом спектакле Арена ди Верона. Образ Дон Жуана может показаться мрачным и деструктивным, но в тоже время он вполне соответствует представлениям о романтическом герое - он как будто сошел со страниц Гофмана, описывающего совершенно другую эпоху: «Одна из дам заметила, что ей пришелся совсем не по вкусу Дон Жуан: слишком уж итальянец был мрачен, слишком уж серьезен и вообще недостаточно легко подошел к игривому и ветреному образу героя».35. Тем не менее, этот образ вполне приемлем и в контексте «посткультуры» с ее всеядностью по отношению ко всем эпохам и культурам, и в контексте исчерпанности культуры, постулируемом постмодернизмом, в котором гедонизм сменяется мрачным разочарованием. Герой Д'Арканджело живет в экзистенциальном вакууме (по теминологии В.Франкла), о чем говорит и сам исполнитель, который посвятил созданию этого образа всю свою творческую жизнь, пройдя через самые разные трактовки. «Лично мне сегодня Дон Жуан представляется персонажем, старающимся заглушить внутреннюю пустоту. То исступление, с которым он ищет внимания женщин, то неистовство, с которым он обольщает их, - это попытка убежать от самого себя. Я думаю, что Дон Жуан есть в каждом из нас. Нужно лишь разобраться в какой форме он в нас проявляется" ${ }^{6}$. Универсальность образа в данном случае не подчеркивается его внешней модернизацией - напротив, все события, приобретающие характер драматического нарратива, развертываются на фоне нарочито преувеличенной и драматизированной барочной роскоши. Сравнивая обе постановки с многочисленными модер-

${ }_{35}$ Там же. С. 88.

${ }^{36}$ http://ru.euronews.com/2012/07/26/don-giovanni-the-greatseducer/ 


\section{Философия культуры}

низированными версиями, (среди экспериментальной креативности которых я так и не нашла достаточно убедительной, что, конечно, во многом субъективно), я не нашла достаточно убедительной, даже при высоком уровне исполнения. Может быть, все же, контекст эпохи, хотя бы и условный, говорит нам больше о человеческих страстях, любви, обмане и смерти, чем темный лес, где заблудились все герои, сложный мир театрального закулисья или современный офис, представленные в весьма известных постановках престижных театров в последние годы?

Другой образ, который также относится к «вечным» - Кармен. И хотя в постановках оперы Ж. Бизе режиссеры часто поддаются соблазнам цыганской экзотики, модернистских экспериментов с этой оперой тоже множество. На наш взгляд, здесь работает тот же контекстный принцип - смысл поступков героев и логика чувств лучше всего раскрываются в контексте нарратива, основанного на литературном первоисточнике - новелле П. Мериме, хотя здесь перед режиссером воз- никает опасность поддаться разнообразным визуальным соблазнам. Лишая эту историю страстной любви и смерти всех внешних атрибутов «народной драмы», можно, казалось бы, лучше раскрыть неприукрашеннуюю правду чувств и связь эроса и танатоса, столь важную в этом произведении. И та, и другая версия имеют право на существование, как в случае всякого «вечного сюжета», при условии, если авторы постановки не будут забывать о музыке, которая, несмотря на популярность «режоперы», все же продолжает оставаться основой оперы. Музыка содержит в себе временную составляющую, стиль своей эпохи, который требует очень тонкого понимания не только формы, но и эмоции, и способа ее выражения, характерного для того или иного времени. Если удается найти точку соединения темпорального и вечного, прошлого и сегодняшнего, тогда возможно создание шедевра. В противоположном случае постмодернистская игра со временем может стать разрушительной как для произведения, так и для исполнителей, и для зрителей/слушателей.

\section{Список литературы:}

1. Адорно Т. Введение в социологию музыки. Университетская книга. М. - Спб, 1999.

2. Гидденс Э. Трансформация интимности. Сексуальность, любовь и эротизм в современных обществах. М.-СПб, Питер, 2004

3. Злотникова Т.С. Эстетические парадоксы режиссуры: Россия, XX век. Ярославль, 2012

4. Камю А. Бунтующий человек. М., Изд-во политической литературы, 1990.

5. Лаури-Вольпи Дж. Параллельные голоса. М.. Аграф, 2011

6. Саид Э.В Культура и империализм. Санкт-Петербург, «Владимир Даль», 2012.

7. Самохвалова В.И. Безобразное: Размышления о его природе, сущности и месте в мире. М.: Брис-М., 2012.

8. Тито Гобби. Мир итальянской оперы. М., Радуга, 1989

9. Фукс Э. Иллюстрированная история нравов. Галантный век. М.. Республика, 1994.

10. Шапинская Е.Н. Дискурс любви. М., Прометей, 1997.

11. Clark K. Civilisation. A Personal View. NY, Harper and Row, 1969.

12. Luhman N. Love as Passion. Cambridge-Oxford, Polity Press, 1986.

13. Jameson, F. Postmodernism, or, the Cultural Logic of Late Capitalism. L.-NY, 1991

14. Riding A., Dunton-Downer L. Opera. Penguin, L.-NY, 2006.

\section{References (transliteration):}

1. $\quad$ Adorno T. Vvedenie v sotsiologiyu muzyki. Universitetskaya kniga. M. - Spb, 1999.

2. Giddens E. Transformatsiya intimnosti. Seksual'nost', lyubov' i erotizm v sovremennykh obshchestvakh. M.-SPb, Piter, 2004

3. Zlotnikova T.S. Esteticheskie paradoksy rezhissury: Rossiya, KhKh vek. Yaroslavl', 2012

4. Kamyu A. Buntuyushchiy chelovek. M., Izd-vo politicheskoy literatury, 1990.

5. Lauri-Vol'pi Dzh. Parallel'nye golosa. M.. Agraf, 2011

6. Said E.V Kul'tura i imperializm. Sankt-Peterburg, «Vladimir Dal'», 2012. 


\section{Культура и искусство 3(15) • 2013}

7. Samokhvalova V.I. Bezobraznoe: Razmyshleniya o ego prirode, sushchnosti i meste v mire. M.: Bris-M., 2012.

8. Tito Gobbi. Mir ital'yanskoy opery. M., Raduga, 1989

9. $\quad$ Fuks E. Illyustrirovannaya istoriya nravov. Galantnyy vek. M.. Respublika, 1994.

10. Shapinskaya E.N. Diskurs lyubvi. M., Prometey, 1997.

11. Clark K. Civilisation. A Personal View. NY, Harper and Row, 1969.

12. Luhman N. Love as Passion. Cambridge-Oxford, Polity Press, 1986.

13. Jameson, F. Postmodernism, or, the Cultural Logic of Late Capitalism. L.-NY, 1991

14. Riding A., Dunton-Downer L. Opera. Penguin, L.-NY, 2006. 